\title{
1 Corinthians 8.4-6: An Inter-cultural Reading From the Political Context of the Democratic People's Republic of Korea (North Korea) Today*
}

\author{
Oh-Young Kwon \\ Whitley College, University of Divinity, Melbourne, Australia
}

\begin{abstract}
This article explores an inter-cultural reading of 1 Corinthians 8.4-6 from the political and ideological contexts of the Democratic People's Republic of Korea (or North Korea; DPRK afterwards) today. The Pauline passage (1 Cor 8.4-6) indicates Roman imperialism and the Imperial cult(s) that had a heavy impact upon the life of people (including Christ-believers) in Roman Corinth of the first century CE. In Roman Imperial cult(s), the Roman emperors were worshipped as divine, and people in the Roman Empire were compelled (at least by social pressure) to honor them as gods. This notion is, to some extent, reflected in the Pauline language- "there may be so-called gods...on earth...there are many gods and many lords" (1 Cor 8.5). The Roman emperors would be seen as amongst these many gods and these many lords in the Pauline description. The DPRK's culture and society is primarily shaped on the foundation of Juche ideology. The Juche literarily means "self-reliance" and emphasizes the DPRK's independence from other countries in terms of its political, ideological, and economic systems. Furthermore, in this Juche ideology Kim Il Sung the founder of the DPRK's communism is claimed as a divine figure, and the people of the DPRK are compelled to venerate and worship him. The discovery of such social, cultural, and religious similarities in the two polarizing contexts encourages me to attempt inter-cultural dialogues between the Christ-believers in first century Corinth and the people of the DPRK today, who appear to see the Juche ideology as the religion officially constituted and recognized in their country today. This attempt makes a contribution to recent Asian Biblical scholarship that would acknowledge and encourage Asian Christians and scholars to read Christian Scriptures from Asian cultural, social, religious, and political contexts.
\end{abstract}

Keywords: Paul, Corinthians, inter-cultural reading, imperial cult(s), Juche ideology, North Korea

\section{Introduction}

This article will explore an inter-cultural reading of 1 Corinthians 8.4-6 from the political and ideological contexts of the Democratic People's Republic of Korea (DPRK hereafter) for Korean Christians in the Korean peninsula - North and South Korea - and elsewhere today. No Korean or international biblical scholars have thoroughly attempted this kind of biblical hermeneutics.

The Pauline text (1 Cor 8.4-6) indicates Roman imperialism and the Imperial cult(s) that had a heavy impact upon the life of people (including Christ-believers) in Roman Corinth of the first century CE. In Roman

\footnotetext{
${ }^{*}$ This article is a revision of the paper that I presented at the 2016 Society of Asian Biblical Studies and Society of Biblical Literature International Meeting held in Seoul in July 2016. I express my gratitude to Rev David Han for his inputs in this article. Oh-Young Kwon, Lecturer in New Testament, Whitley College, University of Divinity.
} 
Imperial cult(s), the Roman emperors were worshipped as divine, and people in the Roman Empire were compelled (at least by social pressure) to honor them as gods. This notion is, to some extent, reflected in the Pauline language - " "there may be so-called gods...on earth...there are many gods and many lords" (1 Cor 8.5; NRSV). The Roman emperors would be seen as amongst these many gods and these many lords in the Pauline description.

The DPRK's culture and society is primarily shaped on the foundation of Juche ideology. The Juche literarily means "self-reliance" and emphasizes the DPRK's independence from other countries in shaping and forming its political, social, and economic systems. The Juche ideology also insists that the DPRK should establish its own "viable national defense system". ${ }^{1}$ Furthermore, in this Juche ideology Kim Il Sung the founder of the DPRK's communism and his son Kim Jong Il are claimed as divine figures, and the people of the DPRK are compelled to venerate and worship them. Today, his young grandson Kim Jung Un is titled and honored as the "Supreme Commander" or "Supreme Leader".

The discovery of such social, cultural, political, and religious similarities in these two polarizing contexts stimulates me to attempt inter-cultural dialogues between the Christ-believers in first century Corinth who were socially pressed and forced to venerate the Roman emperor and the imperial family as gods in the Roman social system of imperial cult(s), and the people and Christians of the DPRK today, who are compelled to honor Kim Il Sung and his son Kim Jong Il as divine figures in the Juche ideology.

Having said that, I now turn to investigating 1 Corinthians 8.4-6 from the perspective of social and political contexts of the Greco-Roman world in the first century CE, in which the Pauline text -1 Corinthians 8.4-6-was composed.

\section{A Social and Political Analysis of 1 Corinthians 8.4-6}

In the literary context of 1 Corinthians 8 , Paul tackles the issues of some of the Christ-believers in Corinth who appear to have eaten food/meats dedicated to idols and participated in pagan temple worship, though they had been converted to Christ. This is reflected in his frequent use of the Greek word eidolothutos $(8: 1,4,7,10)$ and its equivalents eidolon $(8: 4,7)$, eidōleion $(8: 10)$. It is likely, nonetheless, that in 1 Corinthian 8 "Paul pays more attention to whether the behavior of the 'strong' causes wounding to the conscience of the "weak" than whether eating meats offered to pagan gods is idolatry itself. ${ }^{3}$

A careful investigation of the Pauline description of food/meats sacrificed at pagan temples in 1 Corinthians 8 should give much attention to the Greek words, eidolon $(8: 4,7$; cf. 10:19), theos $(8: 5,6 ; 10: 20)$, and kyrios $(8: 5,6$; cf. 10:21) and then analyze these words in close relation to Roman imperialism and the Imperial cult(s). ${ }^{4}$ In chapter 8, these words can be interpreted in several ways except when the words theos and kyrios clearly refer to God the Father (theos ho tatēr, 8:6) and Lord Jesus Christ (kyrios Hēsous Christos, 8:6;

\footnotetext{
${ }^{1}$ Kenneth Bae with Mark Tabb, Not forgotten: The true story of my imprisonment in North Korea (Nashville: W Publishing, 2016), 145, 176; Grace Lee, "The political philosophy of Juche", Stanford Journal of East Asian Affairs, 3(2003), 105-111, esp. 105.

2 Bae, Not forgotten, 119.

3 Oh-Young Kwon, "Discovering the characteristics of collegia-collegia sodalicia and collegia tenuiorum in 1 Corinthians 8, 10 and 15", Horizons in Biblical Theology, 32(2010), 166-182, esp. 169; see also Dennis E. Smith, From symposium to Eucharist: The banquet in the early Christian world (Minneapolis: Fortress, 2003), 209.

${ }^{4}$ For a brief summary of recent scholarly arguments about 1 Corinthians 8, see Oh-Young Kwon, 1 Corinthians 1-4: Reconstructing its social and rhetorical situation and re-reading it cross-culturally for Korean-Confucian Christians today (Eugene: Wipf and Stocks, 2010), 154-156.
} 
cf. 10:21). Derek Newton claims that these words can refer to "a physical image or representation", "a false god", or "heroes and emperors". 5 All these interpretations are plausible in consideration of the social situation of first century Roman Corinth. The city had numerous temples, shrines, and ritual sites, numbering at least 26. ${ }^{6}$ The words, theoi polloi ("many gods") and kyrioi polloi ("many lords") of which Paul speaks in 1 Corinthian 8:5, include the emperor whom some of the Corinthian believers have worshipped and venerated in the imperial cult(s) (1 Cor 8:7). ${ }^{7}$

The imperial cult(s) had been firmly established by the time the early Christian ekklēsia (gathering) was beginning. The imperial cult(s) had already existed in some form in the Roman Empire since the reign of Augustus Caesar, decades before the founding of the Corinthian Christ-believing community. ${ }^{8}$ Furthermore, the imperial cultic system was seen as "one of the most powerful forces towards the unification of the Roman world" in conjunction with patronage that was a significant social system to bind people of different social strata in patron-client relationships. ${ }^{9}$

In the imperial era, emperors such as Julius Caesar (who died in $44 \mathrm{BCE}$ ), Augustus (d. $14 \mathrm{CE}$ ), and Claudius (d. 54 CE) were given divine honors and apotheosized. For example, "at the end of his life, (Julius) Caesar...was appointed a god of the Roman state by the Senate", and Augustus was frequently depicted as "a god on earth or a god-like individual in contemporary poetry and private iconography" and "coinage". ${ }^{10}$

Moreover, the emperor "was transferred among the celestial gods by apotheosis" on his death and "by official act" the senate included him in "the list of Roman deities". ${ }^{11}$ Later, temples were dedicated to Augustus during the reign of Tiberius (d. 37 CE) and of Caligula (d. 41 CE). These temples were ordinarily placed at the center of the provincial capitals where the assembly gathered, such as Roman Corinth, the capital of Achaia. ${ }^{12}$ The people who attended the imperial cult(s) in the Roman Empire expressed their reverence and loyalty and gave divine honors to the emperor, and described him as "patron", "benefactor", "savior", "lord", and "son of a god", suggesting his "greatly superior status". ${ }^{13}$ In the imperial cult(s), the people also acknowledged and appreciated the Pax Romana ("Roman peace") which refers to "Rome's greatest service to the world", and it was "a period of relative peace and stability across the Roman Empire which lasted for over 200 years, beginning with the reign of Augustus (27 BCE-14 CE)". ${ }^{14}$ Similarly, the people of the DPRK today

\footnotetext{
${ }^{5}$ Derek Newton, Deity and diet: The dilemma of sacrificial food at Corinth (Journal for the Study of the New Testament Supplement Series, 169; Sheffield: Sheffield Academic Press, 1998), 285-286.

${ }^{6}$ See Ben Witherington III, New Testament history: A narrative account (Carlisle: Paternoster; Grand Rapids: Baker Academic, 2001), 268-269.

7 Newton, Deity and diet, 288.

8 David Shotter, Augustus Caesar (London; NY: Routledge, 1991), 60; Everett Ferguson, Backgrounds of early Christianity (Grand Rapids: Eerdmans, 1987), 197.

9 Martin Goodman, Rome \& Jerusalem: The clash of ancient civilizations (London: Penguin, 2007), 71; for a detailed explanation of "patronage" see Kwon, 1 Corinthians 1-4, 89-104; also Goodman, Rome \& Jerusalem, 80-91.

${ }^{10}$ Ittai Gradel, Emperor worship and Roman religion (Oxford Classic Monographs; Oxford: Clarendon Press, 2002), 109-110; Goodman, Rome \& Jerusalem, 71.

${ }_{11}^{11}$ Ferguson, Backgrounds of early Christianity, 195-197.

12 Ferguson, Backgrounds of early Christianity, 198.

13 John K. Chow, "Patronage in Roman Corinth" in Richard A. Horsley (Ed.), Paul and empire: Religion and power in Roman imperial society (Harrisburg: Trinity International, 1997), 104-125, esp. 105, 105 n. 5; cf. Bruce W. Winter, After Paul left Corinth: The influence of secular ethics and social change (Grand Rapids: Eerdmans, 2001), 285.

${ }^{14}$ Donald R. Dudley, The civilization of Rome (NY; Toronto: A Mentor Book, 1962), 124; see also Seyoon Kim, Christ and Caesar: The gospel and the Roman empire in the writings of Paul and Luke (Grand Rapids: Eerdmans, 2008), 182; also Helen Rhee, Early Christian literature: Christ and culture in the second and third centuries (London; NY: Routledge, 2005), 164; also Paul Petit, Pax Romana (LA: University of California Press, 1976), 75; http://www.ancient.eu/Pax_Romana/, accessed on $6 / 12 / 2016$.
} 
venerate and honor their deceased leaders as gods and appreciate the Juche ideology (see below).

This notion then helps us understand 1 Corinthians 8:4-6 within its wider literary context of the entire chapter of 1 Corinthians 8. Some of the Corinthian Christ-believers appear to have described themselves as people who possessed knowledge (gnosis) (1 Cor 8:1). Boasting about their gnosis, they conducted themselves arrogantly and acted on it (1 Cor 8:1, 10). In their Corinthian slogan (gnosis) that "no idol in the world really exists" and "there is no God but one" (NRSV; 1 Cor 8.4), they, like their contemporaries in the wider society, continued their membership in a religious club (collegia sodalicia), even after conversion to the Christian faith. In such a religious club, they were associated with those who honored gods as their patron deities and ate food/meats offered as sacrifices to the pagan deities (see 1 Cor 8:7, 10;10:18-20). ${ }^{15}$

Perhaps they attended the imperial cult(s), and dedicated sacrifice to the emperor and called him lord, savior, and god, and implicitly worshipped him as the universal patron (see 1 Cor 8:5). Perhaps some also participated in dinner parties and banquets and ate food/meats sacrificed to deities in the pagan temples and to the emperor in the imperial cult(s) (v.10). ${ }^{16}$

They may well have even regarded the Corinthian Christ-believing community as another of the religious club (collegia sodalicia) where they called on the name of the Christian/Jewish God and the Lord Jesus Christ, worshipped and venerated him as their patron deity, just as they did in other religious clubs in the wider civic society (see 8:4-5).

Furthermore, it is consistent with this inference to suggest that they may well have brought into the Pauline community the hierarchical structures that were usually found in the religious club (collegia sodalicia). From this hierarchical perspective, some of the Corinthian believers of wealth and high social strata would have viewed God as a patron deity ranked at the highest level in the Christ-believing ekklessia. Paul appears to agree, to a certain extent, with this view since he describes God as the Father and Creator through whom all things and people exist (8:6).

Seemingly, this affirms that God can be regarded as a patron deity in Christ-believing communities. They then considered themselves as being ranked in the middle and saw themselves as patrons of the Christian community. This thinking seems to have led them to regard Paul's social status lower than theirs. That is why they expected to give financial supports to Paul as a client. Yet he refused to accept their offer (1 Cor 9:12-23). $\mathrm{He}$ "avoided such patronage by means of self-support in the workshop". ${ }^{17}$ Moreover, they would have viewed the rest of their fellow believers as ranked at a lower level in the social pyramid of the Christ-believing ekklēsia. ${ }^{18}$ They appear to have regarded the Lord's Supper as akin to the banquets and dinner parties of the religious club (collegia sodalicia) and of the temples and the imperial cult(s). There they ate food/meats sacrificed to deities and the emperor.

As would have occurred in such dinner parties, so social discrimination against other fellow believers and especially some members of who were poor and of lower classes at the Lord's Supper (and love-feasts) occurred (see 1 Cor 11:17-22). They did not permit poorer fellow believers to sit around the same table as they did, but they instead left them to eat outside of the building in the courtyard. These poorer and lower-ranked

\footnotetext{
${ }^{15}$ For a detailed explanation of collegia sodalicia, see Kwon, 1 Corinthians 1-4, 154-161; "Discovering characteristics of collegia", 169-175.

${ }_{16}$ Cf. Ferguson, Backgrounds of early Christianity, 180.

${ }^{17}$ Lee A. Johnson, "Paul's epistolary presence in Corinth: A new look at Robert W. Funk's Apostolic Parousia", Catholic Biblical Quarterly, 68(2006): 481-501, esp. 500 n. 46.

${ }^{18}$ See Chow, "Patronage in Roman Corinth", 119.
} 
members seemed to have been provided with poorer quality food. ${ }^{19}$

Paul, however, criticized these unnamed leaders because by doing this, they abused the genuine meaning of the Lord's Supper and Christian hospitality and despised the Christian form of gathering (ekklessia tou theou) where all members should be treated equally as brothers and sisters in Christ regardless of their social classes (1 Cor $3: 8 ; 11: 22){ }^{20}$ On the other hand, they affirmed that the God of Jesus is the one true God—and that the idols/emperors were not true gods (8:4) — therefore, it did not matter in other respects if they participated in banquets and dinner parties in the broader Corinthian civic society.

Nevertheless, Paul, by using the traditional Jewish understanding that idolatry leads to immorality, strongly denounced and condemned the social consequences of idol worship in the temples, where attendees and worshippers often behaved immorally especially in terms of sexual licentiousness and prostitution (1 Cor 9:8-12; 10:1-13). This notion is supported by R. E. Ciampa and B. S. Rosner stating that Paul took "the Old Testament and Jewish" or "the traditional Jewish approach to dealing with sexual immorality and idolatry" in 1 Corinthians $8 .^{21}$ Paul wished to protect his Corinthian Christ-believing ekklēsia from such immorality and then enhance and uphold Christian ethics and morals in it (see 1 Cor 5:9-11). He says, "We must not indulge in immorality" (1 Cor 10:8).

For these reasons, Paul critiqued as demonic the patron deities that some members in the Corinthian congregation implicitly venerated at the religious club (collegia sodalicia) and Greco-Roman pagan temples and then encouraged them to stop such worship of idols (see 1 Cor 10:14). Their conduct further harmed and wounded some Christ-believers who were weak, although they did not necessarily intend or notice this (1 Cor 8:7), resulting in factions (schismata) within the Christ-believing ekklēsia (see 1 Cor 11:18-9). Paul suggests, therefore, that they should take care lest their behaviour become an obstacle to the weak (1 Cor 8:9), lest it wound the other brothers and sisters' conscience (syneidessis) (1 Cor 8:10), and lest it cause the weak to fall. Moreover, Paul argues that it is a sin against Christ to wound the conscience of the brothers and sisters in the Corinthian congregation (8:7-13), because this partly caused the Corinthian Christ-believers to split into schisms (schismata) (see 1:10; 11:18-19; 12:25).

Furthermore, Paul had a strong emphasis on unity in the Corinthian Christ-believing community as the body of Christ (soma Christou) (1 Cor 12:1-31). He also claimed that the Corinthian Christ-believers should have love (agapē) for one another (1 Cor 8:1; 13:1-13). Particularly in 1 Corinthians 13:13, "so faith (pistis), hope (elpis), love (agapē) abide, these three; but the greatest of these is love", Paul values agape more highly than pistis and elpis. ${ }^{22} \mathrm{He}$ seems to assert that to have agape for one another is the most necessary and important way to reclaim the Corinthian congregation from the unhealthy environment of factionalism.

All these findings motivate and encourage me to re-read 1 Corinthians 8.4-6 inter-culturally from the political and ideological contexts of the DPRK today and evaluate the Pauline message for Korean Christians in

\footnotetext{
${ }^{19}$ See Keith Dyer, "Eating words in the New Testament" in Alan Cadwallader (Ed.), Stones, bones, and the sacred: Essays on material culture and ancient religion in honor of Dennis E. Smith (Atlanta: SBL Press, 2016), 69-84, esp. 76-79; also Jerome Murphy-O'Connor, St. Paul's Corinth: Texts and archaeology (3rd ed.; Collegeville: The Liturgical Press, 2002), 183-184.

${ }^{20}$ Ben Witherington III, Conflict \& community in Corinth: A socio-rhetorical commentary on 1 and 2 Corinthians (Grand Rapids: Eerdmans; Carlisle: Paternoster, 1995), 184.

${ }^{21}$ Roy E. Ciampa \& Brian S. Rosner, The first letter to the Corinthians (Grand Rapids: Eerdmans; Nottingham: Apollos, 2010), 389; "The structure and argument of 1 Corinthians: A biblical/Jewish approach", New Testament Studies, 52(2006): 205-218, esp. 218.

${ }^{22}$ See Dennis E. Smith, From Symposium to Eucharist: The banquet in the early Christian world (Minneapolis: Fortress, 2003), 211; also Christian Stettler, "The 'Command of the Lord' in 1 Cor 14:37-A saying of Jesus?" Biblica, 87(2006): 42-51, esp. 46.
} 
the Korean peninsula and elsewhere.

\section{An Inter-cultural Reading of 1 Corinthians 8.4-6 From the Political and Ideological Contexts of the DPRK Today}

The DPRK is "one of the "most repressive and secretive states on earth" for decades. ${ }^{23}$ So it is commonly regarded as a "hermit kingdom". ${ }^{24}$ North Korea has maintained and preserved itself as an isolated society from the rest of the world for a long time because of its Juche ideology (which literarily means self-reliance). This Juche ideology is articulated and exhibited in all areas of the society of North Korea, and serves as the fundamental foundation of all the political, social, and economic systems of North Korea. This Juche ideology insists that North Korea should be completely independent from foreign powers and international aids in order to form and maintain its own political, social and economic systems. It instead claims that the whole nation must be totally dependent on "the wisdom and leadership of the ruling member of the Kim family" - Kim Il Sung (1912-1994), the founder of the Juche ideology. He was succeeded by his son Kim Jong Il (1941-2011) and currently by his grandson Kim Jong Un (1983-). ${ }^{25}$ The Kim family has been ruling and dictating North Korea for over 60 years since 1948.

The Juche ideology was first developed in 1950s after the Korean War (mid 1950-mid 1953) and clearly outlined in the speech of Kim Il Sung at the Supreme People's Assembly on December 16, 1967. Kim says,

The Government of the Republic will implement with all consistency the line of independence, self-sustenance, and self-defense to consolidate the political independence of the country (jahju in Korean), build up more solidly the foundations of an independent national economy capable of insuring the complete unification, independence, and prosperity of our nation (jahrip) and increasing the country's defense capabilities, so as to safeguard the security of the fatherland reliable by our own force (jahwi), by splendidly embodying our Party's idea of juche in all fields. ${ }^{26}$

The Juche ideology highlights three elements-North Korea's political independence from foreign powers, its economic prosperity and its self-defense system with its own military force. Then, this Juche ideology was recognized as the official state ideology of North Korea in $1972 .{ }^{27}$ Moreover, this Juche ideology is stipulated in the North Korean Constitution and the Workers' Party Charter in which it is described as "the guiding principle" for all the actions of North Korea, and that the Workers' Party is directed and "guided only by Kim Il Sung's Juche ideology and his revolutionary thoughts". ${ }^{28}$ As a result of this, the Juche ideology has become the propaganda of North Korea's communism and the political platform for Kim Il Sung and his son Kim Jong Il and now his grandson Kim Jong Un to obtain and maintain the absolute power and authority over the people of North Korea for over 60 years. ${ }^{29}$

Notwithstanding, North Korea's economy is in critical position now. It seems hard to survive. It may collapse in near future. The 2016 Index of Economic Freedom exhibits its economic status. North Korea is

\footnotetext{
${ }^{23}$ Barbara Demick, Nothing to envy: Real lives in North Korea (London: Granta Publications, 2014), cover page.

24 Demick, Nothing to envy, 57; Yeonmi Park, In order to live: A North Korean girl's journey to freedom (London: Penguin Books, 2016), 4; Kang Chol-Hwan \& Pierre Rigoulot, The Aquariums of Pyongyang: Ten years in the North Korean Gulag (London: Atlantic Books, 2006), 226.

${ }_{25}$ See Park, In order to live, 33, 46-49, 64-65, 257; Hyeonseo Lee with David John, The girl with seven names: Escape from North Korea (London: William Collins, 2015), 17, 35.

${ }^{26}$ Lee, "Political Philosophy of Juche", 105-106; also Yuk-Sa Li (Ed.), Juche! The speeches and writings of Kim Il Sung (New York: Grossman, 1997), 156.

${ }^{27}$ Lee, "Political Philosophy of Juche", 105; also Don Oberdorfer, The two Koreans (Mass: Addison Wesley, 1997), 401.

28 See http://www2.law.columbia.edu/course_00S_L9436_001/North\%20Korea\%20materials/3.html, accessed on 8/11/2016.

29 See Demick, Nothing to envy, 287.
} 
ranked at the bottom in global economy as well as in Asia-Pacific regional economy. It is ranked at number 178 out of about 193 countries in the world and at number 42 out of about 50 countries in the Asia-Pacific region. ${ }^{30}$ Moreover, the majority of North Korean people are suffering from food shortage or food insecurity. North Korean refugees who escaped from the DPRK and live in South Korea and USA testify that millions of people have been dying of starvation. ${ }^{31}$

UN figures show up to 70 percentage of the country remains food insecure and 28 percentage of children under the age of five are stunted due to malnutrition. Due to this kind of chronic food shortages hundreds of thousands are believed to have died during a famine in the mid-to-late 1990s — with the situation exacerbated by floods, droughts and mismanagement. International food aid, especially from South Korea and the United States, has been drastically cut amid tensions over the communist state's nuclear and Missile programs. ${ }^{32}$

This data explicitly points out that the Juche ideology fails to drive and strengthen the economic prosperity of the DPRK and fails to care about its people. And yet it is convinced that the ideology has been abused by its dictators to reinforce their communist propaganda and keep their absolute power over the people for decades.

Furthermore, the Juche ideology is misused to deify, apotheosize, and idolize the two deceased leaders Kim Il Sung and Kim Jong Il. ${ }^{33}$ The Juche ideology claims that there is no god but Kim Il Sung is venerated as "a god" and "eternal president ruling the country in spirit from the confines of his climate-controlled mausoleum beneath the Tower of Eternal Life", and his son Kim Jong Il as "the son of a god, a Christ-like figure". ${ }^{4}$ It further "attributes divine power also to Kim Jong Il as the sole author, editor and interpreter" of Kim Il Sung's Juche ideology. ${ }^{35}$ Then this divine power has now passed on to Kim Jong Un. ${ }^{36}$

There are notes to support that the deification of Kim Il Sung and his son Kim Jong Il has taken place in North Korea. Wi Jo Kang describes,

In North Korea school children are required to bow down to the statues of North Korean dictator Kim Il Sung, and are given their choice of praying to the statue or praying to God. If they pray to God, then they get no rice for lunch, but if they pray to Kim Il Sung, then they get a full portion. Children who consistently refuse to bow to Kim Il Sung and call him their "beloved" Father have been shot, along with the entire families, as examples to the bourgeois (in French people who belong to the middle class) and un-proletarianized elements in North Korean society (words in italic mine). ${ }^{37}$

Daniel Schwekendiek also gives an example of the deification of Kim Il Sung.

At Kim Il Sung's personality cult where he is deified...Objects touched by Kim Il Sung...would be put into a showcase...places visited would be renamed by the date he came, or spots where he stood would be sanctified. Institutions set up chapels to worship the leader, and all citizens were made to bow to the portrait of the North Korean leader before and after sleeping.... and after his death he was named "eternal president"- acknowledging him as having an immortal and divine statue. In 1997 North Korea would even introduce its own calendar that virtually replaced the birth of Christ with

\footnotetext{
${ }^{30}$ See http://www.heritage.org/index/country/northkorea, accessed on 7/12/2016.

31 See Demick, Nothing to envy, 7; see also Kang \& Rigoulot, Aquariums of Pyongyang, xxii.

32 See https://www.yahoo.com/news/drought-sparks-fears-worsening-food-shortages-n-korea-115723895.html?ref=gs, accessed on $7 / 12 / 2016$.

${ }^{33}$ See Network for North Korean Democracy and Human Rights (NKnet hereafter), NK human rights: A global perspective (Seoul: NKnet, 2015), 14.

${ }_{35}$ Demick, Nothing to envy, 9, 122; see also Bae, Not forgotten, 40, 84.

35 See http://northkoreanchristians.com/juche-idea.html, accessed on 8/11/2016.

${ }^{36}$ Lee, Girl with seven names, 289.

37 Wi Jo Kang, Christ and Caesar in modern Korea: A history of Christianity and politics (Albany: State University of New York Press, 1997), 84.
} 
Kim Il Sung's birth year as the basis of calculation. ${ }^{38}$

There are over 500 statues of Kim Il Sung in North Korea. ${ }^{39}$ Moreover, there are erected two 22-meter-high bronze statues of Kim Il Sung and his son Kim Jong Il side by side at the Grand Monument on Mansu Hill, the central area of Pyongyang, the capital of North Korea. ${ }^{40}$ The North Korean people are expected to lay flowers and, moreover, they are forced to bow at the feet of these statues and render respect and homage for their late leaders who are believed to continue on ruling the people under the propaganda of the Juche ideology. Bowing in front of their statues is mandatory. All the people must do it. Even tourists are expected to bow before the statues. ${ }^{41}$ Likewise, through the effectiveness of the Juche ideology in the society of North Korea Kim Il Sung is honored as a god-like figure. ${ }^{42}$

Having noted this, we now turn to pondering how Christians in North Korea react to the claim that Kim Il Sung is believed as a god and Kim Jong Il as son of god. ${ }^{43}$ It is estimated that there are $200,000-300,000$ Christians in the DPRK, and that most of these Christians scatter around over 1,200 underground churches as well as secret house churches out of its total population of 25 million that is half size of South Korea's population-over 50 million. $^{44}$

In North Korea, there exist two different groups of Christians in nature. One group of Christians belongs to state-recognized churches. There are reported four state-sanctioned churches in Pyongyang - one Catholic and one Russian Orthodox and two Protestants-ChilGohk Church and BongSoo Church. In addition, in 2005 Pyongyang Jeil Gyohoi (Pyongyang First Chapel/Church) was newly established. And yet it does not function as a church today, but it exists as a prayer center. ${ }^{45}$ The Christians who belong to these churches seem not to denounce or refuse the Juche ideology and the deification of Kim Il Sung and Kim Jung Il. These Christian people and their leaders are trained by the government to show off to the rest of the world that North Korea encourages its people to have the right to freedom of religion or belief and that there exist Christians and religious facilities in the country. The DPRK guarantees freedom of religion by its constitution. And yet there is, in fact, no practice of other religions in the country at all, but the people are socially compelled and pressured to worship their young dictator Kim Jung Un and his predecessors. ${ }^{46}$

The other group of Christians belongs to underground churches that are not recognized by the government. They practice their Christian faith in secret and refuse to bow before the statues and portraits of Kim Il Sung and Kim Jong Il in public. They neither support the Juche ideology and the idolization of the deceased leaders. They rather choose to be imprisoned and persecuted by their communist government, when their secret practice of Christian faith is exposed and disclosed. In 2014, it was reported that "a minimum of 80,000 to a maximum of 120,000 political criminals" including Christian people were confined in five different concentration/prison camps-“'Unit 14 (Gaecheon), Unit 15 (Yoduk), Unit 16 (Myeonggan), Unit 18 (Gaechon, old Bukchang), and

\footnotetext{
${ }^{38}$ Daniel Schwekendiek, A socioeconomic history of North Korea (Jefferson: McFarland, 2011), 34.

39 See https://en.wikipedia.org/wiki/Kim_Il-sung, accessed on 8/12/2016.

40 See NKnet, NK human rights, 14.

${ }^{41}$ See http://edition.cnn.com/2013/12/02/travel/north-korea-tourist-protocol, accessed on 8/12/2016.

42 See Jiyoung Song, Human rights discourse in North Korea: Post-colonial, Marxist and Confucian perspectives (London; NY: Routledge, 2011), 127.

43 See Bae, Not forgotten, 84, 176.

44 See NKnet, NK human rights, 16.

45 Yim Hee Kook, Gihdarim kwa suhduhrum uhi yuhksa: Hankook Jangrhokyoheh 130 yyuhn (History of waiting and hasty: 130 years of the Korean presbyterian church) (Seoul: Korean Presbyterian Seminary Press, 2013), Ch. 14.

46 See NKnet, NK human rights, 16-18.
} 
Unit 25 (Cheongjin)". ${ }^{47}$ Whereat political prisoners work long hours. They are frequently subjected to torture and executed. Likewise, these North Korean people and Christians endure extremely harsh and repressive conditions. ${ }^{48}$

I wonder how these North Korean Christians would read the Pauline instruction of church-state relationship in Romans 13.1-5 for themselves in such difficult situations.

v.1 Let every person be subject to the governing authorities; for there is no authority except from God, and those authorities that exist have been instituted by God.

v.2 Therefore whoever resists authority resists what God has appointed, and those who resist will incur judgment.

v.3 For rulers are not a terror to good conduct, but to bad. Do you wish to have no fear of the authority? Then do what is good, and you will receive its approval.

v.4 for it is God's servant for your good. But if you do what is wrong, you should be afraid, for the authority does not bear the sword in vain! It is the servant of God to execute wrath on the wrongdoer.

v.5 Therefore one is necessary to submit, not only because of the wrath (ho orgē) but also because of the conscience (ho syneidesis). (New Revised Standard Version; italics mine).

In this Pauline text, Paul expressed his opinion on authority (exousia) that refers to government/state authority(ies) rather than to angelic authority(ies). ${ }^{49} \mathrm{He}$ appears to have encouraged his readers to acknowledge their state authority(ies) that was instituted and appointed by God (vv.1-2). He further seems to have urged them to be subject to the authority(ies) in order to avoid its wrath and outrage upon the Christ-believers (v.5). Presumably, Paul would argue that their subjection to the state authority(ies) would be temporal or for a short period of time. Paul addresses nowhere in the text that they should be subject to government authorities at all times.

By the time this Roman text was written, the Roman Christ-believers suffered persecutions, and many of them had been executed for their (public) confession and declaration of faith in Jesus Christ (see Rom 8.35-39). Meanwhile, Paul reminds them in his eschatological framework that all institutional powers on earth including the Roman Empire were under the control of God (v.1). Then, he points out that the suffering and persecution that the Roman Christ-believers faced should not be "worth comparing with the glory about to be revealed to" them (Rom 8.18).

Furthermore, I understand that Paul would address his words in rhetorical strategic plans. He would deliberately emphasize that his readers did nothing wrong or they were not wrongdoers to the Roman government authority(ies) (v.4). They rather performed good conducts in their civic society. Thus, they would receive an approval of their good conduct from God in the near future (v.3). Paul further argues that the decision should be up to the Roman Christ-believers whether they would submit to their state authority(ies) because they might have fear of it (v.3) or whether they would refuse to be subject to it because of their conscience of faith in Christ Jesus as Lord and Savior (v.5).

Nonetheless, in the passage Paul undoubtedly legitimates government/state authority(ies). He also notes that submission or subjection to government authority(ies) and paying tax to it were collectively considered as part of the Christ-believing life as rational beings (see Rom $12.1 ; 13.1,6-7){ }^{50}$ It should not be overlooked, however, that in the text Paul does not mean to provide a theory of the state or that he does not express his

\footnotetext{
${ }^{47}$ NKnet, NK human rights, 20-21.

48 See Kang, Aquariums of Pyongyang, xxiv.

49 See Thomas R. Schreiner, Romans: Baker exegetical commentary on the New Testament (Grand Rapids: Baker, 1998$), 681$.

${ }^{50}$ See Brendan Byrne, Romans (Collegeville: Liturgical, 1996), 388.
} 
concern about the nature of the Roman authority(ies). And yet he is deeply concerned about the life of the Roman Christ-believers within their civic society under the rule of Roman authorities. ${ }^{51} \mathrm{He}$ further sympathizes and empathizes with them who were persecuted by the Roman authority(ies) (see Rom 5.1-4). Hence, Paul urges his Roman readers as rational beings to comply, to some extent, with government requirements, e.g., legitimation of authorities and payment of taxes (Rom 12.1). ${ }^{52}$ With this interpretation, I hope to encourage and comfort North Korean people who keep their Christian faith in difficult circumstances and who are persecuted by the dictator, Kim Jug Un, and his communist ruling authorities today. Having noted this, we now turn to exploring hermeneutical implications of 1 Corinthians 8.4-6 in the Christian context of the DPRK.

\section{Hermeneutical Implications}

As observed above, there are two different groups of Christians in the DPRK. One group supports the communist government's propaganda and Juche ideology, while the other group refuses to support it and choose to be persecuted for their conscience of faith. To be assumed, there would be tensions and conflicts between the two groups within the Christian community of the DPRK.

This notion reminds us that, as seen above, there were factions among the members in the Pauline community in Corinth due to their different viewpoints and practices over the issue of eating meat dedicated to idols and to the Roman emperors deceased and living in the imperial cult(s) described in 1 Corinthians 8.4-6. Some Corinthian Christians attended the imperial cult(s) where they honored the emperor as god and participated in banquets and ate food/meat sacrificed to the imperial family members. Others refused to attend the imperial cult(s) and banquets or dinner parties for the sake of their conscience and faith in God who is Creator ( 1 Cor 8.6). This caused conflicts and divisions amongst the Corinthian Christ-believers (1 Cor 1.10-12). In 1 Corinthians 8.12, therefore, Paul argues that they should not offend or wound the conscience of other fellow believers. He further exhorts and encourages them to have agape love for one another (1 Cor 13.1-13) and to be united as one body in one Spirit (1 Cor 12.12-13). With this Pauline message, I would encourage and urge our North Korean Christians, who are divided over the issue of ideology, not to offend one another or not to wound one another's conscience. Moreover, they should be united in one body, one Lord, one God and one Spirit.

Furthermore, another substantial similarity in the two polarizing political and social contexts - the Roman world in the first century CE and the DPRK today - is that one refused or refuses to pay homage to the ruler(s) deceased and living, the person was not or is not given provision or provided food at all.

In the Roman Empire, people who did not attend the imperial cult(s) or did not honor the emperor as god at the imperial cult(s) were not invited to banquets or dinner parties held at imperial temples afterwards. Whereat the food that was distributed to guests had been sacrificed at the imperial cult(s) or at pagan temples. Hence, the Christ-believers in Corinth refused to participate in the imperial cult(s) and refused to eat the food sacrificed at imperial temples because in their thinking the participation and eating would cause them to idolatry (1 Cor 10.1-21).

Similarly, if people in the DPRK do not support the Juche ideology or do not bow before the statues and portraits of the late dictators Kim Il Sung and Kim Jong Il and the present dictator Kim Jung Un, then they are

\footnotetext{
51 See Arland J. Hultgren, Paul's letter to the Romans (Grand Rapids: Eerdmans, 2011), 472.

52 See Byrne, Romans, 362.
} 
provided no food or no other resources and materials. They are completely banned from the state's aid. Inevitably, North Korean people's daily life heavily relies on the state's provision. So their veneration to the deceased and living dictators and their support for the Juche ideology are not a matter of choice. It is a must-to-do for the people to survive. And yet Christians in North Korea refuse to support the juche ideology and the deification of the Kim family. They rather choose to be persecuted and die for their conscience of faith in God (see above).

To them the Pauline message in 1 Corinthians would be appropriate and relevant. One group of North Korean Christians, whether they support or refuse the Juche ideology and the idolization of the Kim family, should take into account the conscience of the other group (1 Cor 8.12). Moreover, both groups should practice the love of Christ towards each other in the wider Christian community of their country (1 Cor 13.1-13). They can find a way that they will be united in the love of Christ, one body, one God and one Spirit (1 Cor 12.12-13). Then this Pauline message can reclaim the Christian community in the DPRK from the destructive environment of conflicts and divisions.

Especially the Pauline message of agape love should be most necessary for Christians in the DPRK, who need to practice it towards one another and other people who have their human rights threatened by enslavement, torture, detention, forced abortion, imprisonment, persecution, and so on. ${ }^{53}$ The United Nations recently described the DPRK the worst among the world's principal offenders of human rights. ${ }^{54}$ The Christian message of agape love is also necessary for North Korean refugees who scatter in South Korea and other Western countries like USA and UK. They find it difficult and hard to adjust and accommodate themselves to new culture and new society. They are often discriminated by locals. And the agape message is needed for North Korean asylum-seekers who are abused as illegal immigrants and live in life-threatening circumstances in Asian countries like China. ${ }^{55}$

\section{Conclusion}

This essay has been hermeneutically engaged in inter-cultural dialogues between Christian Scriptures - especially Paul's letters - and the DPRK's political and ideological contexts today. This inter-cultural reading of the Bible highly values and appreciates our contemporary cultural traditions and customs, and social, economic and political contexts that make a significant contribution to (re)shaping our Christian faiths and traditions. This inter-cultural reading further encourages us to bring our own socio-cultural, socio-economic, and socio-political wrestles and struggles and insights into reading the Bible for ourselves and our readers and audience.

Moreover, this inter-cultural reading invites and helps us to imagine that we are actively engaged in dynamic and vital dialogues with the biblical authors and their audience through our reading of their writings, though there is a gap of thousands years. In these dialogues, we bring our own social, political, cultural, and spiritual issues and ask the biblical writers and their readers for advice, comment, and feedback on the issues. For these reasons, this essay has attempted to read 1 Corinthians 8.4-6 inter-culturally for North Korean people and Christians today in terms of their political and ideological contexts.

\footnotetext{
${ }^{53}$ See NKnet, NK human rights, 23; also Bae, Not forgotten, 100-200; Kang, Aquariums of Pyongyang, 53-140; Demick, Nothing to envy, 134-215.

${ }_{54}$ See NKnet, $N K$ human rights, 25.

55 See Park, In order to live, 69-152; also Lee, Girl with seven names, 82-165.
} 
Furthermore, this essay wishes to make a contribution to strengthening and enhancing the atmosphere of reconciliation and reunification between the two Koreas. This is one of the most important and crucial issues that Korean Christians and churches and educational organizations in the Korean peninsula and overseas take into account as part of their ministry and theological emphasis.

Lastly, this essay makes a contribution to biblical scholarship today that promotes and fosters inter-cultural and cross-cultural readings between Christian Scriptures and 21st century contemporary issues domestic and international, and to Asian Biblical scholarship today that acknowledges and encourages Asian Christians and scholars to read Christian Scriptures from the perspective of Asian cultural, social, religious, and political contexts for Asian readers.

\section{References}

2016 index of economic freedom: North Korea. (2016). Retrieved from http://www.heritage.org/index/country/northkorea Bae, K., \& Tabb, M. (2016). Not forgotten: The true story of my imprisonment in North Korea. Nashville: W Publishing. Byrne, B. (1996). Romans. Collegeville: Liturgical.

Chow, J. K. (1997). Patronage in Roman Corinth. In R. A. Horsley (Ed.), Paul and empire: Religion and power in Roman imperial society (pp. 104-125). Harrisburg: Trinity International.

Ciampa, R. E., \& Rosner, B. S. (2006). The structure and argument of 1 Corinthians: A biblical/Jewish approach. New Testament Studies, 52, 205-218.

Ciampa, R. E., \& Rosner, B. S. (2010). The first letter to the Corinthians. Grand Rapids: Eerdmans; Nottingham: Apollos.

Demick, B. (2014). Nothing to envy: Real lives in North Korea. London: Granta Publications.

Drought sparks fears of worsening food shortage in N. Korea. (2015, June 18). Retrieved from https://www.yahoo.com/news/drought-sparks-fears-worsening-food-shortages-n-korea-115723895.html?ref=gs

Dudley, D. R. (1962). The civilization of Rome. NY; Toronto: A Mentor Book.

Dyer, K. (2016). Eating words in the New Testament. In A. Cadwallader (Ed.), Stones, bones, and the sacred: Essays on material culture and ancient religion in honor of Dennis E. Smith (pp. 69-84). Atlanta: SBL Press.

Ferguson, E. (1987). Backgrounds of early Christianity. Grand Rapids: Eerdmans.

Goodman, M. (2007). Rome \& Jerusalem: The clash of ancient civilizations. London: Penguin.

Gradel, I. (2002). Emperor worship and Roman religion. Oxford Classic Monographs; Oxford: Clarendon Press.

Hultgren, A. J. (2011). Paul's letter to the Romans. Grand Rapids: Eerdmans.

Johnson, L. A. (2006). Paul's epistolary presence in Corinth: A new look at Robert W. Funk's apostolic Parousia. Catholic Biblical Quarterly, 68, 481-501.

Juche ideology. (n.d.). Retrieved from http://www2.law.columbia.edu/course_00S_L9436_001/North\%20Korea\%20materials/3.html

Kang, C. H., \& Rigoulot, P. (2006). The Aquariums of Pyongyang: Ten years in the North Korean Gulag. London: Atlantic Books.

Kang, W. J. (1997). Christ and Caesar in modern Korea: A history of Christianity and politics. Albany: State University of New York Press.

Kim, S. (2008). Christ and Caesar: The gospel and the Roman empire in the writings of Paul and Luke. Grand Rapids: Eerdmans.

Kwon, O. Y. (2010, August). 1 Corinthians 1-4: Reconstructing its social and rhetorical situation and re-reading it cross-culturally for Korean-Confucian Christians today. Eugene: Wipf and Stocks.

Kwon, O. Y. (2010, June). Discovering the characteristics of collegia-collegia sodalicia and collegia tenuiorum in 1 Corinthians 8 , 10 and 15. Horizons in Biblical Theology, 32, 166-182.

Lee, G. (2003). The political philosophy of Juche. Stanford Journal of East Asian Affairs, 3, 105-111.

Lee, H., \& John, D. (2015). The girl with seven names: Escape from North Korea. London: William Collins.

Li, Y. S. (Ed.). (1997). Juche! The speeches and writings of Kim Il Sung. New York: Grossman.

Murphy-O'Connor, J. (2002). St. Paul's Corinth: Texts and archaeology (3rd ed.). Collegeville: The Liturgical Press.

Network for North Korean Democracy and Human Rights (NKnet). (2015). NK human rights: A global perspective. Seoul: NKNet Press. 
Newton, D. (1998). Deity and diet: The dilemma of sacrificial food at Corinth. Journal for the Study of the New Testament Supplement Series, 169. Sheffield: Sheffield Academic Press.

North Korean Christians.com: The Juche idea. (2013). Retrieved from http://northkoreanchristians.com/juche-idea.html Oberdorfer, D. (1997). The two Koreans. Mass: Addison Wesley.

Park, Y. (2016). In order to live: A North Korean girl's journey to freedom. London: Penguin Books.

Pax Romana. (2015, December 8). Retrieved from http://www.ancient.eu/Pax_Romana/

Petit, P. (1976). Pax Romana. LA: University of California Press.

Rhee, H. (2005). Early Christian literature: Christ and culture in the second and third centuries. London; NY: Routledge.

Schreiner, T. R. (1998). Romans: Baker exegetical commentary on the new testament. Grand Rapids: Baker.

Schwekendiek, D. (2011). A socioeconomic history of North Korea. Jefferson: McFarland.

Shotter, D. (1991). Augustus Caesar. London; NY: Routledge.

Smith, D. E. (2003). From symposium to Eucharist: The banquet in the early Christian world. Minneapolis: Fortress.

Song, J. (2011). Human rights discourse in North Korea: Post-colonial, Marxist and Confucian perspectives. London; NY: Routledge.

Stettler, C. (2006). The "Command of the Lord" in 1 Cor 14:37-A saying of Jesus? Biblica, 87, 42-51.

What can tourists expect when visiting North Korea?. (2013, December 13). Retrieved from http://edition.cnn.com/2013/12/02/travel/north-korea-tourist-protocol

Wikipedia: Kim Il-sung. (2017, May 1). Retrieved from https://en.wikipedia.org/wiki/Kim_Il-sung

Winter, B. W. (2001). After Paul left Corinth: The influence of secular ethics and social change. Grand Rapids: Eerdmans.

Witherington, B III. (1995). Conflict \& community in Corinth: A socio-rhetorical commentary on 1 and 2 Corinthians. Grand Rapids: Eerdmans; Carlisle: Paternoster.

Witherington, B III. (2001). New Testament history: A narrative account. Carlisle: Paternoster; Grand Rapids: Baker Academic.

Yim, H. K. (2013). Gihdarim kwa suhduhrum uhi yuhksa: Hankook Jangrhokyoheh 130 yyuhn (History of waiting and hasty: 130 years of the Korean presbyterian church). Seoul: Korean Presbyterian Seminary Press. 